\title{
Possible Actions of Corticotropin-Releasing Hormone in Regulating Porcine Corpus Luteum Function
}

\author{
Ryosuke SAKUMOTO ${ }^{1) *}$, Shuichi ITO'2) and Tokushi KOMATSU ${ }^{3)}$ \\ ${ }^{1)}$ Reproductive Biology Research Unit, National Institute of Agrobiological Sciences, Ibaraki 305-0901, ${ }^{2)}$ Department of Animal Science, \\ Tokai University, Kumamoto 869-1414 and ${ }^{3)}$ National Agricultural Research Center for Tohoku Region, Iwate 020-0198, Japan
}

(Received 2 March 2010/Accepted 9 April 2010/Published online in J-STAGE 23 April 2010)

\begin{abstract}
The objective of the present study was to determine whether corticotropin-releasing hormone (CRH) influences porcine corpus luteum function. The gene expressions of CRH receptors (CRH-R) were determined in the CLs of Chinese Meishan pigs during the estrous cycle. The effects of CRH on progesterone $(\mathrm{P})$, estradiol-17 $\beta(\mathrm{E})$ and prostaglandin $(\mathrm{PG}) \mathrm{F}_{2 \alpha}$ secretion by cultured luteal cells were also investigated. Messenger RNAs of the $C R H-R$ were clearly expressed in the CL throughout the estrous cycle, and the mRNA level was higher at the regressed stage than at the other stages $(\mathrm{P}<0.05)$. When the cultured luteal cells obtained from the mid-luteal stage CL (days 8-11) were exposed to CRH $(50-5000 \mathrm{ng} / \mathrm{ml}$ ), P secretion by the cells was significantly reduced at the highest dose $(\mathrm{P}<0.05)$, whereas $\mathrm{CRH}$ had no effect on $\mathrm{E}$ and $\mathrm{PGF}_{2 \alpha}$ secretion by the cells. The overall results suggest that $\mathrm{CRH}$ inhibits local $\mathrm{P}$ production from luteal cells via its specific CRH-R, implying that CRH plays some roles in regulating porcine CL function during the estrous cycle, especially in the period of luteolysis.
\end{abstract}

KEY WORDS: corpus luteum, corticotropin-releasing hormone, receptor, swine.

J. Vet. Med. Sci. 72(9): 1173-1177, 2010

Corticotropin-releasing hormone $(\mathrm{CRH})$ is known as a stress-induced peptide that is secreted from the paraventricular nucleus of the hypothalamus [22]. Hypothalamic CRH induces adrenocorticotropic hormone (ACTH) secretion by the pituitary via its specific receptors (CRH-R), and the ACTH stimulates glucocorticoid (GC) production from the adrenal gland; this is considered to be the hypothalamicpituitary-adrenal (HPA) axis [22]. GC is produced in the adrenal cortex during periods of stress and is widely recognized as an immunosuppressive and anti-inflammatory agent [2]. It has been shown to inhibit expression of cytokines, adhesion molecules and enzymes involved in the inflammatory process [4]. Our recent study demonstrated the presence of GC and its converting enzymes in the porcine corpus luteum (CL) and that GC inhibits steroid production from cultured luteal cells [21], suggesting that GC may regulate CL function locally in pigs.

Recent studies indicate that a CRH/CRH-R system also exists outside the central nervous system. CRH and CRH-R have been identified in the human placenta $[8,17]$, endometrium $[11,12]$ and ovaries $[3,14]$. In monkeys, the genes and proteins for CRH and CRH-R are expressed in the $\mathrm{CL}$ during the menstrual cycle [24]. Moreover, CRH inhibits progesterone $(\mathrm{P})$ and estradiol-17 $\beta(\mathrm{E})$ secretion by cultured human granulosa-lutein cells [7]. Since the E production from the CL in pigs is a specific feature that is similar to those of the CLs in humans and monkeys [23], the previous studies lead us to hypothesize that CRH directly regulates CL function in pigs as well as in primates.

In the present study, therefore, we measured expression

* Correspondence to: Dr. Sakumoto, R., Reproductive Biology Research Unit, National Institute of Agrobiological Sciences, Ibaraki 305-0901, Japan.

e-mail: sakumoto@affrc.go.jp of CRH-R in the porcine CL from different stages of the estrous cycle using reverse transcription (RT) polymerase chain reaction (PCR) and real-time PCR analyses. The possible effects of $\mathrm{CRH}$ on $\mathrm{P}, \mathrm{E}$ and prostaglandin $(\mathrm{PG}) \mathrm{F}_{2 \alpha}$ secretion by cultured luteal cells were also studied.

\section{MATERIALS AND METHODS}

Collection of porcine corpora lutea: Sixteen post-pubertal Chinese Meishan pigs (50 to $90 \mathrm{~kg}$ ) were used for the analysis of mRNA abundance. Each pig was euthanized by electric shock as is usually done in local abattoirs. The luteal stage was classified as early (days 3-5 after ovulation), mid (days 8-11), late (days 14-16) or regressed (days 19-21) by macroscopic observation of the ovaries [1] and confirmed by measuring P concentrations in CLs ( $n=4 /$ each stage). For gene expression studies, the CLs were immediately separated from the ovaries, frozen rapidly in liquid nitrogen and stored at $-80^{\circ} \mathrm{C}$ until use.

Four post-pubertal Chinese Meishan pigs (55-70 kg) were used for cell culture studies. Ovaries with mid-stage CLs were collected, submerged in ice-cold physiological saline and transported to the laboratory. Ten to sixteen CLs were pooled from each pig $(\mathrm{n}=4)$.

$P C R$ : Total RNA isolation and subsequent RT- and realtime PCR steps were carried out as previously described [20]. The following primers encoding the porcine sequences were designed and synthesized: 5'-GCCGCCTACAACTATTTCCA-3', forward, and 5'-CCAGCCAATGCAGATAAACA-3 (132 bp), reverse, for $C R H-R 1$ (NM_001144110; specific for porcine CRH receptor type 1).

Gene expression was measured by real-time PCR using a LightCycler (Roche Diagnostics, Mannheim, Germany) and 
the QuantiTect ${ }^{\circledR}$ SYBR Green PCR system (Qiagen GmbH, Hilden, Germany) starting with $10 \mathrm{ng}$ of reverse-transcribed total RNA. GAPDH expression was used as an internal control. The primer sequences for GAPDH amplification were: 5'-GGGCATGAACCATGAGAAGT-3', forward, and 5'TGTGGTCATGAGTCCTTCCA-3' (133 bp), reverse. For quantification of the mRNA expression levels, the primer length (20 bp) and GC-contents of each primer (50-60\%) were selected, and PCR was performed under the following conditions: $95^{\circ} \mathrm{C}$ for $15 \mathrm{~min}$, followed by 55 cycles of $94^{\circ} \mathrm{C}$ for $15 \mathrm{sec}, 55^{\circ} \mathrm{C}$ for $30 \mathrm{sec}$ and $72^{\circ} \mathrm{C}$ for $30 \mathrm{sec}$. Use of the QuantiTect ${ }^{\mathbb{B}}$ SYBR Green PCR system at elevated temperatures resulted in reliable and sensitive quantification of the RT-PCR products with high linearity (Pearson's correlation coefficient: $r>0.98$ ).

Luteal cell culture: Porcine luteal cells were prepared and cultured as described previously with some modifications $[18,20]$.

Viable luteal cells $\left(5 \times 10^{5} /\right.$ well $)$ obtained from mid-stage CLs were cultured in DMEM/F12 (DMEM and Ham's F-12 medium, 1:1 [v/v]; D8900; Sigma-Aldrich Inc., St. Louis, MO, U.S.A.) supplemented with $10 \%$ calf serum (C6278; Sigma-Aldrich) and $20 \mu \mathrm{g} / \mathrm{m} l$ gentamicin (15710-072; Gibco BRL ${ }^{\circledR}$ Life Technologies, Rockville, MD, USA) in 24-well culture plates (3524; Costar, Cambridge, MA, U.S.A.) for up to $48 \mathrm{hr}$ in a humidified atmosphere of $5 \%$ $\mathrm{CO}_{2}$ in air at $37.5^{\circ} \mathrm{C}$. For the final $24 \mathrm{hr}$ of culture, the cells were exposed to ovine CRH (50-5000 $\mathrm{ng} / \mathrm{ml}$; 4111-s; Peptide Institute, Inc., Osaka, Japan) in fresh culture medium. The conditioned media were collected and stored at $-30^{\circ} \mathrm{C}$ until measurement of $\mathrm{P}, \mathrm{E}$ and $\mathrm{PGF}_{2 \alpha}$. To determine whether the cultured cells were responsive to luteinizing hormone (LH), the cells were treated with porcine LH (100 $n \mathrm{~g} / \mathrm{ml}$; Biogenesis Ltd., England, UK) for $24 \mathrm{hr}$. Four separate experiments were conducted using the CLs from four pigs.

Hormone determinations: The $\mathrm{P}$ concentrations were determined using an EIA as described previously [19]. The samples for the $\mathrm{P}$ assay were diluted 1000 -fold with assay buffer. The standard curve ranged from 0.49 to $125 \mathrm{ng} / \mathrm{ml}$, and the $\mathrm{ED}_{50}$ of the assay was $3.2 \mathrm{ng} / \mathrm{ml}$. The average intraand interassay coefficients of variation were $7.1 \%$ and $10.1 \%$, respectively.

The E concentrations were determined using a commercial EIA kit (582251; Cayman Chemical Company, Ann Arbor, MI, U.S.A.). The samples for the E assay were diluted 11-fold with assay buffer. The standard curve ranged from 7.8 to $1000 \mathrm{pg} / \mathrm{ml}$, and the $\mathrm{ED}_{50}$ of the assay was $29.1 \mathrm{pg} / \mathrm{ml}$. The average intra- and interassay coefficients of variation were $9.4 \%$ and $12.4 \%$, respectively.

The $\mathrm{PGF}_{2 \alpha}$ concentrations were determined directly using an EIA as described previously [18]. The samples for the $\mathrm{PGF}_{2 \alpha}$ assay were diluted five-fold with assay buffer. The standard curve ranged from 15.6 to $4000 \mathrm{pg} / \mathrm{ml}$, and the $\mathrm{ED}_{50}$ of the assay was $225 \mathrm{pg} / \mathrm{ml}$. The average intra- and interassay coefficients of variation were $8.9 \%$ and $12.8 \%$, respectively.
Statistical analyses: All experimental data are shown as the mean \pm SEM. The statistical significance of differences in the abundance of mRNA expression and in the concentrations of $\mathrm{P}, \mathrm{E}$ and $\mathrm{PGF}_{2 \alpha}$ in culture media was assessed by one-way ANOVA with the StatView 5 (SAS Institute Inc., Cary, NC, U.S.A.) software package. When ANOVA showed a significant effect of stage, the stages were compared by the Fisher's protected least significant difference procedure (PLSD) as a multiple comparison test. A probability value less than 0.05 was considered statistically significant.

\section{RESULTS}

Expressions of CRH-R mRNA in the porcine CL during the estrous cycle: Specific transcripts for $C R H-R$ were detected in the porcine CL throughout the estrous cycle as well as in the pituitary, which was used as a positive control (Fig. 1A). Real-time PCR analysis showed that the abundance of $C R H-R$ mRNA in the CL was higher at the regressed stage of the estrous cycle than at the other stages (Fig. 1B; $\mathrm{P}<0.05$ ).

Effects of CRH on hormone secretion by cultured luteal cells: CRH $(5000 \mathrm{ng} / \mathrm{m} l)$ significantly inhibited P secretion by the cultured porcine luteal cells (Fig. $2 \mathrm{~A} ; \mathrm{P}<0.05$ ), whereas it did not affect $\mathrm{E}$ and $\mathrm{PGF}_{2 \alpha}$ secretion (Figs. 2B and $2 \mathrm{C}$ ) at any of the doses tested. $\mathrm{LH}$, used as a positive control for the reactivity of the cultured luteal cells, significantly stimulated $\mathrm{P}$ secretion by the cells (Fig. 2A) and inhibited $\mathrm{PGF}_{2 \alpha}$ secretion (Fig. 2C).

\section{DISCUSSION}

The present study provides evidence for the existence of mRNAs for $C R H-R$ in the porcine CL throughout the estrous cycle. In addition, since $\mathrm{CRH}$ inhibited $\mathrm{P}$ secretion by cultured luteal cells, a functional CRH-R seems to be expressed on porcine luteal cells. CRH is known to possess two distinct receptors, type 1 (CRH-R1) and type 2 (CRH$\mathrm{R} 2$ ), that are coupled to two 7-transmembrane $\mathrm{G}$ proteins (Gs and Gq), respectively [6]. Since CRH-R1 has been shown to be expressed mainly in the CL in monkeys [24] and ovaries in rats [16], the presence of $C R H-R 1$ mRNA was evaluated in this study. Messenger RNAs for $C R H-R 1$ were expressed at the highest levels in the CL of the regressed stage in the present study. In addition, higher levels of immunoreactive CRH have been found in the regressing CL compared with the developing CL in humans [15], suggesting that $\mathrm{CRH}$ plays a role at this stage. However, the CRH concentrations in the CLs of monkeys [24], humans [14] and rats [13] have been demonstrated to increase in the developing luteal stage and to decrease in the regressing stage. Further study is needed to clarify the CRH production profile and the concrete roles of $\mathrm{CRH}$ in the porcine $\mathrm{CL}$ at the time of luteolysis.

Previous studies have demonstrated that $\mathrm{CRH}$ affects steroidogenesis in mammals. CRH at doses comparable to 
A) $\mathrm{CRH}-\mathrm{R}(132 \mathrm{bp})$
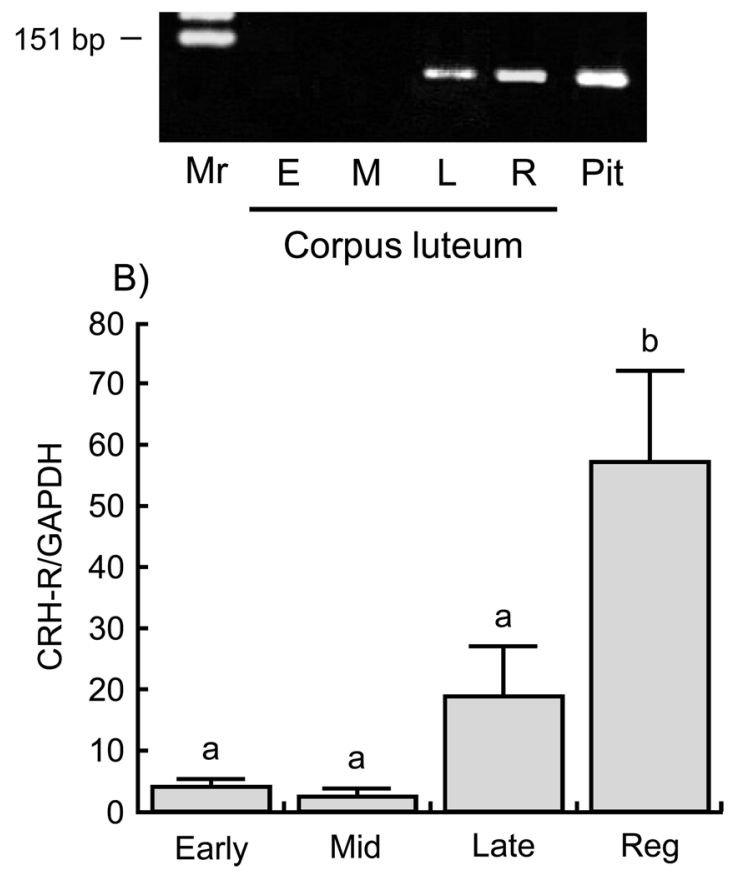

Fig. 1. A) Representative examples of the specific RT-PCR products for $C R H-R$ separated by agarose gel electrophoresis. Lanes: E, early stage; $M$, mid-stage; L, late stage; R, regressed stage; Pit, pituitary (positive control); Mr, DNA marker ladder. B) $C R H-R$ gene expression in the porcine CL during the estrous cycle. Data are the means \pm SEM for 4 pigs per group and are expressed as the relative ratio of $C R H-R$ mRNA to GAPDH mRNA. Different letters indicate significant differences $(\mathrm{P}<0.05)$.

those used in the present study inhibits $\mathrm{P}$ and $\mathrm{E}$ secretion by human granulosa-lutein cells [7] and the basal and FSHinduced $\mathrm{E}$ secretion by rat granulosa cells [5]. Hence, we expected that $\mathrm{P}$ and $\mathrm{E}$ secretion by the porcine cultured luteal cells would be inhibited by CRH. However, in the present study, CRH inhibited $\mathrm{P}$ secretion by cultured porcine luteal cells, whereas it did not affect $\mathrm{E}$ and $\mathrm{PGF}_{2 \alpha}$ production. In other words, our results do not agree with the above previous studies, except for the result for P. On the other hand, it has been demonstrated that $\mathrm{CRH}$ can stimulate steroid production from several tissues. CRH increases E production from cultured human placental cells [25] and stimulates steroidogenesis by increasing the synthesis of the steroidogenic acute regulatory proteins in mouse Leydig cells that play a role in transferring cholesterol across the mitochondrial membrane [10]. Although the reason for the discrepancy is unclear, it might be due to differences in species and the conditions of the cell culture systems between the previous and present studies.

Completion of luteal regression is known to involve apoptotic cell death in many species including pigs [23]. CRH is also known to be secreted from the hypothalamus under
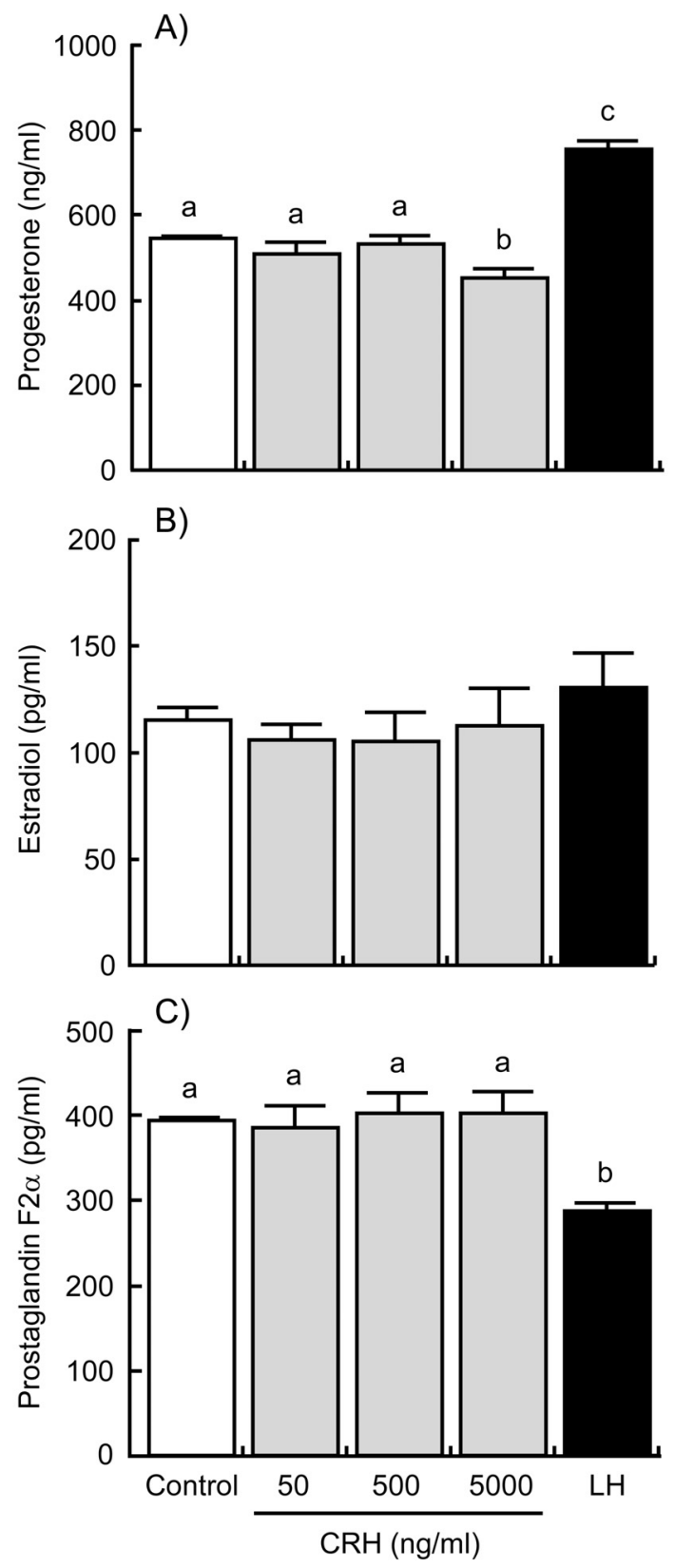

Fig. 2. Effects of CRH on A) progesterone, B) estradiol-17 $\beta$ and $\mathrm{C}$ ) prostaglandin $\mathrm{F}_{2 \alpha}$ secretion by cultured luteal cells collected from the mid-luteal stage CL. Data are expressed as means \pm SEM for four separate experiments, each run in triplicate. Different letters indicate significant differences $(\mathrm{P}<0.05)$. LH: luteinizing hormone $(100 \mathrm{ng} / \mathrm{m} l)$.

the conditions of stress. Hypothalamic CRH induces ACTH secretion by the pituitary and subsequent production of GC from the adrenal gland [22]. Since GC is widely recognized to inhibit cytokine-induced apoptosis via its receptor in a variety of tissues [4], GC plays major roles as an antiinflammatory factor in many organs. The porcine CL pro- 
duces PGs throughout the luteal phase and regresses in response to uterine $\mathrm{PGF}_{2 \alpha}$ [23]. Furthermore, immune cells have been demonstrated to invade the porcine CL during $\mathrm{PGF}_{2 \alpha}$-induced luteolysis [9]. Since the inflammatory response involves the actions of cytokines, which are produced by immune cells, and since many cytokines stimulate production of PGs by the cells of target organs [2], it is possible that the CL during luteolysis is subject to inflammatory-like conditions. Our previous study demonstrated that GC inhibits $\mathrm{P}$ and $\mathrm{PGF}_{2 \alpha}$ secretion by cultured porcine luteal cells [21]. Therefore, this suggests that $\mathrm{CRH}$ directly inhibits $\mathrm{P}$ production in the $\mathrm{CL}$ and that $\mathrm{CRH}$-induced $\mathrm{GC}$ also plays a role in suppressing the inflammatory-like process in the regressed CL in pigs.

In conclusion, our results clearly demonstrated that $\mathrm{CRH}$ $R$ mRNAs are expressed in the porcine CL throughout the estrous cycle. Since CRH inhibited $\mathrm{P}$ production by luteal cells and $C R H-R$ mRNA expression was highest in the regressed CL, we suggest that $\mathrm{CRH}$ plays one or more roles in regulating porcine CL function during the estrous cycle, especially at the time of luteolysis.

ACKNOWLEDGMENTS. This research was supported by a Grant-in-Aid for Scientific Research (No. 17780212) from the Japan Society for the Promotion of Science. The authors thank the staff of the Swine Management Section of the National Institute of Livestock and Grassland Science for their skilled technical assistance and Dr. Seiji Ito, Kansai Medical University, for the antiserum against $\mathrm{PGF}_{2 \alpha}$.

\section{REFERENCES}

1. Akins, E.L. and Morrissette, M.C. 1968. Gross ovarian changes during estrous cycle of swine. Am. J. Vet. Res. 29: 1953-1957.

2. Amsterdam, A. and Sasson, R. 2002. The anti-inflammatory action of glucocorticoids is mediated by cell type specific regulation of apoptosis. Mol. Cell. Endocrinol. 189: 1-9.

3. Asakura, H., Zwain, H.I. and Yen, S.S. 1997. Expression of genes encoding corticotropin-releasing factor (CRF) type 1 CRF receptor, and CRF-binding protein and localization of the gene products in the human ovary. J. Clin. Endoclinol. Metab. 82: 2720-2724.

4. Barnes, P.J. and Adcock, I. 1993. Anti-inflammatory actions of steroids: molecular mechanisms. Trends Pharmacol. Sci. 14: 436-441.

5. Calogero, A.E., Burrello, N., Negri-Cesi, P., Papale, L., Palumbo, M.A., Cianci, A., Sanfilippo, S. and D'Agata, R. 1996. Effects of corticotrophin-releasing hormone on ovarian estrogen production in vitro. Endocrinology 137: 4161-4166.

6. Dautzenberg, F.M. and Hauger, R.L. 2002. The CRF peptide family and their receptors: yet more partners discovered. Trends Pharmacol. Sci. 23: 71-77.

7. Ghizzoni, L., Mastorakos, G., Vottero, A., Barreca, A., Furlini, M., Cesarone, A., Ferrari, B., Chrousos, G.P. and Bernasconi, S. 1997. Corticotropin-releasing hormone (CRH) inhibits steroid biosynthesis by cultured human granulosa-lutein cells in a $\mathrm{CRH}$ and interleukin-1 receptor-mediated fashion. Endocrinology 138: 4806-4811.

8. Hatzoglou, A., Margioris, A.N., Bakogeorgou, E., Gravanis, A. and Castanas, E. 1996. Identification, characterization and localization of corticotropin-releasing hormone receptors in human placenta. Life Sci. 59: 1871-1879.

9. Hehnke, K.E., Christenson, L.K., Ford, S.P. and Taylor, M. 1994. Macrophage infiltration into the porcine corpus luteum during prostaglandin $\mathrm{F}_{2 \alpha}$-induced luteolysis. Biol. Reprod. 50: $10-15$.

10. Huang, B.M., Stocco, D.M., Li, P.H., Yang, H.Y., Wu, C.M. and Norman, R.L. 1997. Corticotropin-releasing hormone stimulates the expression of the steroidogenic acute regulatory protein in MA-10 mouse cells. Biol. Reprod. 57: 547-551.

11. Karteris, E., Papadopoulos, N., Grammatopoulos, D.K. and Hillhouse, E.W. 2004. Expression and signaling characteristics of the corticotrophin-releasing hormone receptors during the implantation phase in the human endometrium. J. Mol. Endocrinol. 32: 21-32.

12. Makrigiannakis, A., Zoumakis, E., Margioris, A.N., Theodoropoulos, P., Stournaras, C. and Gravanis, A. 1995. The corticotropin-releasing hormone $(\mathrm{CRH})$ in normal and tumoral epithelial cells of human endometrium. J. Clin. Endoclinol. Metab. 80: 185-189.

13. Mastorakos, G., Webster, E.L., Friedman, T.C. and Chrousos, G.P. 1993. Immunoreactive corticotropin-releasing hormone and its binding sites in the rat ovary. J. Clin. Invest. 92: 961968.

14. Mastorakos, G., Scopa, C.D., Vryonidou, A., Friedman, T.C., Kattis, D., Phenekos, C., Merino, M.J. and Chrousos, G.P. 1994. Presence of immunoreactive corticotropin-releasing hormone in normal and polycystic human ovaries. J. Clin. Endocrinol. Metab. 79: 1191-1197.

15. Muramatsu, Y., Sugino, N., Suzuki, T., Totsune, K., Takahashi, K., Tashiro, A., Hongo, M., Oki, Y. and Sasano, H. 2001. Urocortin and corticotropin-releasing factor receptor expression in normal cycling human ovaries. J. Clin. Endocrinol. Metab. 86: 1362-1369.

16. Nappi, R.E. and Rivest, S. 1995. Stress-induced genetic expression of a selective corticotropin-releasing factor-receptor subtype within the rat ovaries: an effect dependent on the ovulatory cycle. Biol. Reprod. 53: 1417-1428.

17. Riley, S.C., Walton, J.C., Herlick, J.M. and Challis, J.R. 1991. The localization and distribution of $\mathrm{CRH}$ in the human placenta and fetal membranes throughout gestation. J. Clin. Endocrinol. Metab. 72: 1001-1007.

18. Sakumoto, R., Berisha, B., Kawate, N., Schams, D. and Okuda, K. 2000. Tumor necrosis factor- $\alpha$ and its receptor in bovine corpus luteum throughout the estrous cycle. Biol. Reprod. 62: 192-199.

19. Sakumoto, R., Kasuya, E., Saito, T. and Akita, T. 2004. A technique for long-term implantation of a microcatheter into the third ventricle of post-pubertal Chinese Meishan pigs based on ventriculography. J. Neurosci. Methods 137: 97-101.

20. Sakumoto, R., Komatsu, T., Kasuya, E., Saito, T. and Okuda K. 2006. Expression of mRNAs for interleukin-4, interleukin-6 and their receptors in porcine corpus luteum during the estrous cycle. Domest. Anim. Endocrinol. 31: 246-257.

21. Sakumoto, R., Ito, S. and Okuda, K. 2008. Changes in expression of mRNAs for $11 \beta$-hydroxysteroid dehydrogenase (HSD) type-1, type-2 and glucocorticoid receptor in porcine corpus luteum during the estrous cycle. Mol. Reprod. Dev. 75: 925 930.

22. Swanson, L.W. and Sawchenko, P.E. 1980. Paraventricular nucleus: A site for the integration of neuroendocrines and autonomic mechanisms. Neuroendocrinology 31: 410-7. 
23. Wuttke, W., Pitzel, L., Knoke, I., Theiling, K. and Jarry, H. 1997. Immune-endocrine interactions affecting luteal function in pigs. J. Reprod. Fertil. (Suppl.) 52: 19-29.

24. Xu, J., Xu, F., Hennebold, J.D., Molskness, T.A. and Stouffer, R.L. 2007. Expression and role of the corticotrophin-releasing hormone/urocortin-receptor- binding protein system in the pri- mate corpus luteum during the menstrual cycle. Endocrinology 148: 5385-5395.

25. You, X., Yang, R., Tang, X., Gao, L. and Ni, X. 2006. Corticotropin-releasing hormone stimulates estrogen biosynthesis in cultured human placental trophoblasts. Biol. Reprod. 74: 10671072. 